\title{
Genome modularization reveals overlapped gene topology is necessary for efficient viral
}

\section{reproduction}

\author{
Bradley W Wright ${ }^{1}$, Juanfang Ruan ${ }^{2,3}$, Mark P Molloy $^{4^{*}}$, Paul R Jaschke ${ }^{1^{*}}$ \\ ${ }^{1}$ Department of Molecular Sciences, Macquarie University, Sydney, NSW, Australia \\ ${ }^{2}$ Electron Microscope Unit, Mark Wainwright Analytical Centre, The University of New South \\ Wales, Sydney, NSW, Australia \\ ${ }^{3}$ School of Biotechnology and Biomolecular Sciences, The University of New South Wales, Sydney, \\ NSW, Australia \\ ${ }^{4}$ Kolling Institute, Northern Clinical School, The University of Sydney, Sydney, NSW, Australia \\ ${ }^{4}$ Corresponding authors. Correspondence and requests for materials should be addressed to PRJ \\ (paul.jaschke@mq.edu.au) and MPM (m.molloy@sydney.edu.au)
}

Corresponding Author Addresses:

Paul R. Jaschke

Department of Molecular Sciences,

Macquarie University

Sydney, NSW 2109

AUSTRALIA

Mark P. Molloy

Faculty of Medicine and Health,

Northern Clinical School,

The University of Sydney

Sydney, NSW 2006

AUSTRALIA 
Running Title: Gene overlaps and viral reproduction

\section{ABSTRACT}

Sequence overlap between two genes is common across all genomes, with viruses having high proportions of these gene overlaps. The biological function and fitness effects of gene overlaps are not fully understood, and their effects on gene cluster and genome-level refactoring are unknown. The bacteriophage $\phi \times 174$ genome has $\sim 26 \%$ of nucleotides involved in encoding more than one gene. In this study we use an engineered $\phi X 174$ phage containing a genome with all gene overlaps removed, to show that gene overlap is critical to maintaining optimal viral fecundity. Through detailed phenotypic measurements we reveal that genome modularization in $\phi \times 174$ causes virion replication, stability, and attachment deficiencies. Quantitation of the complete phage proteome across an infection cycle reveals almost half the proteins display abnormal expression patterns. Taken together, we have for the first time comprehensively demonstrated that gene modularization severely perturbs the coordinated functioning of a bacteriophage replication cycle. This work highlights the biological importance of gene overlap in natural genomes and that reducing gene overlap disruption should be an integral part of future genome engineering projects.

\section{KEYWORDS}

bacteriophage, genome engineering, proteomics, synthetic biology, virus structure

\section{INTRODUCTION}

The arrangement of genes within a genome is well recognised to be an important feature in the regulation of gene expression (Cavalli \& Misteli, 2013, Chen \& Stein, 2006, Harmston, IngSimmons et al., 2017, Lanctôt, Cheutin et al., 2007, Lawrence, 2002, Lim, Lee et al., 2011, Tsochatzidou, Malliarou et al., 2017) and as such, gene order tends to be evolutionarily conserved 
(Dandekar, Snel et al., 1998, Davila Lopez, Martinez Guerra et al., 2010, Herniou, Olszewski et al., 2003, Minot, Wu et al., 2012, Poyatos \& Hurst, 2007, Singer, Lloyd et al., 2004, Tamames, 2001). Studies have investigated implications of ectopic gene expression revealing functional significance to gene order (Endy, You et al., 2000, Flanagan, Schoeb et al., 2003, Pesko, Voigt et al., 2015, Wakimoto \& Hearn, 1990). For example, studies in bacteriophage T7 have highlighted the criticality of gene ordering in achieving the upper limits of fitness (Endy et al., 2000, Springman, Badgett et al., 2005), and significantly, this fitness attenuating gene re-ordering is difficult to purge even after long-adaptation cycles (Cecchini, Schmerer et al., 2013). Therefore, despite important functional significance revealed by these studies, rules surrounding the relationship of genome architecture and phenotypic outcome are still only loosely defined.

In addition to gene order, another related feature of genome topology has been gene sequence overlap, which is common across viral (Belshaw, Pybus et al., 2007, Brandes \& Linial, 2016), prokaryotic (Huvet \& Stumpf, 2014, Johnson \& Chisholm, 2004) and eukaryotic (Chung, Wadhawan et al., 2007, Mouilleron, Delcourt et al., 2015, Neme \& Tautz, 2013) genomes, and as such, is increasingly thought to be a critical component of genome architecture (Johnson \& Chisholm, 2004, Pavesi, Vianelli et al., 2018, Sanna, Li et al., 2008, Schlub \& Holmes, 2020, Veeramachaneni, Makałowski et al., 2004). In the model eukaryote yeast, overlaps are prevalent, with approximately $18 \%$ of genes overlapping, majority of which lie in untranslated regions (UTR) (Sun, Yang et al., 2015). In viruses, gene overlaps are more prevalent and seem to be a result of hard constraints put on genome size as a result of capsid assembly and stability, restricting genome length and nucleotide composition (Brandes \& Linial, 2016, Chirico, Vianelli et al., 2010). Once in place, gene overlaps also seem to have some role in gene expression regulation (David, 2000, Jin, Vacic et al., 2008, Johnson \& Chisholm, 2004, Lapidot \& Pilpel, 2006).

In prokaryotes and viruses, whereby gene overlap is often found within open reading frames (Johnson \& Chisholm, 2004, Schlub \& Holmes, 2020), the overlap is thought to arise from 
mutations resulting in start codon creation within existing genes, or between adjacent genes by mutations removing start or stop codons (Delaye, DeLuna et al., 2008, Van Oss \& Carvunis, 2019).

This results in 5' or 3' extensions of the existing gene into the adjacent gene (Delaye et al., 2008, Van Oss \& Carvunis, 2019). This phenomenon is often called overprinting (Keese \& Gibbs, 1992) and may also occur on the anti-sense strand, typically resulting in the generation of non-protein encoding but functionally relevant cis or trans-acting RNA (Brantl, 2002).

Only a few studies have investigated changes to fitness from uncoupling (modularising) gene overlap (Chan, Kosuri et al., 2005, Fernandes, Faust et al., 2016, Ghosh, Kohli et al., 2012, Jaschke, Lieberman et al., 2012, Li, Ma et al., 2007). With one exception, in which the desired pathway product was increased (Li et al., 2007), modularisation has resulted in fitness loss (Chan et al., 2005, Fernandes et al., 2016, Ghosh et al., 2012, Jaschke et al., 2012), but to date, no study has defined the molecular mechanisms underlying these fitness defects.

The functional effects of gene overlap disruption are extremely pertinent to genome engineering and refactoring projects, which frequently disrupt sequence overlaps during reconfiguration of native genes and pathways. A number of projects have cautiously sought to minimise the potential impacts of overlap disruption through explicit design choices such as overlap sequence duplication (Baba, Ara et al., 2006, Hutchison, Chuang et al., 2016, Lajoie, Kosuri et al., 2013), but these efforts to address the biological implications of gene overlap disruption have been ad-hoc. As such, there is no consensus regarding how to treat gene overlaps in genome engineering and refactoring projects.

In this study, we comprehensively define the range of phenotypes displayed by a whole genome modularised bacteriophage that was constructed previously (Jaschke et al., 2012). The aptly named 'decompressed' $\phi \times 174$ had all instances of gene overlap modularised, which had previously constituted $16.8 \%$ of the wild-type genome. The decompressed $\phi \times 174$ genome modifications removed gene overlaps of both entirely overprinted genes (genes B within A, K 
within $A$ and $C$, and $E$ within D) as well as start/stop overlaps of tandem same-strand gene

overlaps (genes B-K, A-C, K-C, C-D, D-J) (Figure 1), while maintaining absolute genome length, codon usage bias, and $\mathrm{G}+\mathrm{C}$ content (Jaschke et al., 2012).

Initial characterization of the resulting phage revealed comparable lysis efficiency with respect to the wild-type strain under the limited conditions tested (Jaschke et al., 2012). To build upon that work, here we have deeply characterized decompressed $\phi$ X174 using targeted proteomics to temporally resolve the complete proteome of decompressed and wild-type $\phi \times 174$ across an entire infection cycle. We find that decompressed $\phi X 174$ conceals severe deficiencies in several key replication proteins and displays a broad range of phenotypic issues. As a result of this work we gain new insights into the effect of genome modularisation and highlight the need to consider gene overlaps as a critical component of genome architecture, especially in the context of future genome engineering projects.

\section{(A) Wild-type $\Phi \mathrm{X174}$}

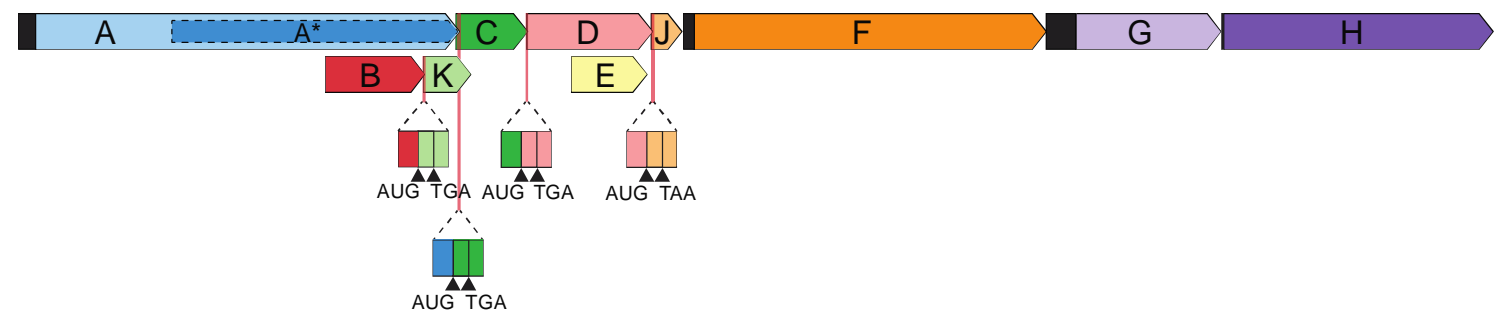

\section{(B) Decompressed $\Phi \mathrm{X} 174$}

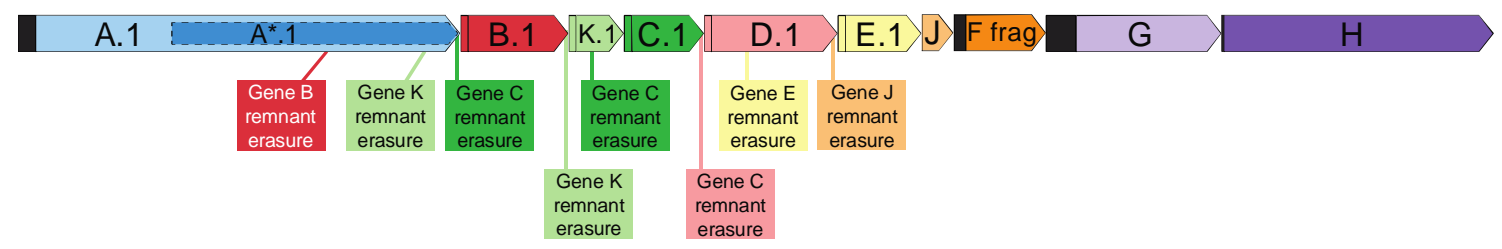

Figure 1: Wild-type and decompressed $\phi X 174$ genome topologies. (A) In the wild-type $\phi X 174$ genome, genes $B$ and $E$ are examples of overprinted gene overlap while tandem same-strand start/stop codon overlaps are shown for overlaps between genes B-K, A-C, C-D, and D-J. (B) In the decompressed $\$$ X174 genome all overprinted genes and start/stop codon overlaps are removed. Locations of synonymous codon modification to remove legacy start codons and ribosome binding sites are shown. Genes with the .1 nomenclature have had synonymous codon changes in at least one location within the gene. 


\section{RESULTS AND DISCUSSION}

\section{Decompressed $\varphi \times 174$ displays comparable lysis timing but impaired progeny production}

To understand more deeply the phenotypic effects of removing all overlaps from the genome of bacteriophage $\phi \times 174$, we first performed plaque assays and liquid growth assays of decompressed $\phi X 174$. Double-agar overlay plaque assays of wild-type and decompressed $\phi X 174$ phage preparations infecting Escherichia coli C122(pJ804(Gene F)) strain under gene F inducing conditions (necessary for decompressed $\phi \times 174$ reproduction) showed that the decompressed $\phi X 174$ plaque size was significantly smaller at $4.1 \pm 0.9 \mathrm{~mm}^{2}$ compared to $29.2 \pm 8.0 \mathrm{~mm}^{2}$ for wildtype $\phi X 174$ (p-value $<0.00001$ ) (Figure $2 A$ ).

During phage infection, there is an intricate balance between progeny production and lysis initiation, and there are a range of factors that can decrease plaque size, including decreased latent period or burst-size (Abedon \& Culler, 2007a, Abedon \& Culler, 2007b, Gallet, Kannoly et al., 2011). The $\phi X 174$ protein $E$ mediates host lysis, with an estimated 500 molecules sufficient to cause membrane disruption and cell death (Zheng, Struck et al., 2009). If decompressed $\phi X 174$ was producing protein E sooner in the infection cycle than wild-type $\phi \times 174$ or was producing less E protein, that may explain the reason for smaller plaque size due to reduced progeny production from premature lysis or inefficient lysis.

To determine whether lysis-timing or lack of effective lysis was the cause of the decompressed $\phi \mathrm{X} 174$ small-plaque phenotype, we infected exponentially growing $E$. coli C122(pJ804(Gene F)) strain with either decompressed or wild-type $\phi X 174$ with a multiplicity of infection (MOI) = 5 and measured culture absorbance for 60-minutes. We used a high phage load to ensure the majority (>99\%) of host cells had one or more phage attached and we were only observing the effects of one infection cycle. The results of this time-course showed that decompressed and wild-type $\phi$ X174 have comparable lysis timing under our conditions (Figure 2B) with no evidence for phage cross-contamination (Appendix Figure S1). 
We next measured the burst-size of decompressed $\phi X 174$ to determine if the small-plaque phenotype could be due to fewer viable progeny produced per infected cell. We determined the burst-size of wild-type $\phi \times 174$ to be $145 \pm 66$ phage produced per cell while decompressed $\phi \times 174$ produced only $16 \pm 2$ phage per cell. Previous measurements of wild-type $\phi X 174$ burst-size have reported between 160-180 phage produced per cell (Brown, Stancik et al., 2013, Gillam, Atkinson et al., 1985, Hutchison \& Sinsheimer, 1966).

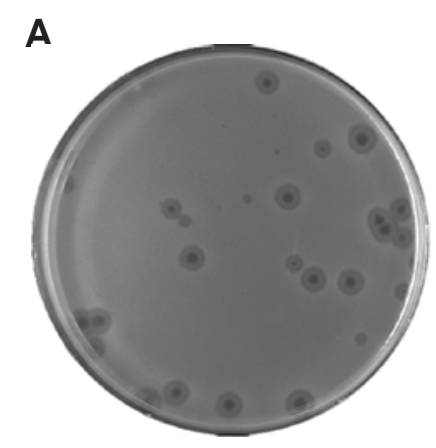

WT $ø X 174$

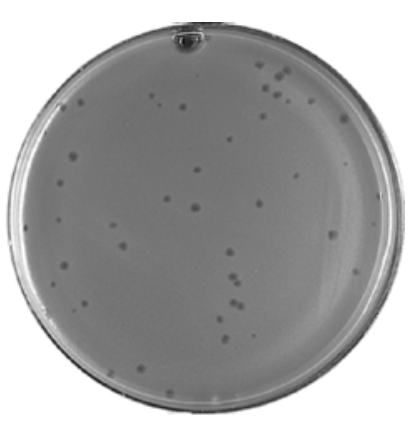

Decompressed ø174

B

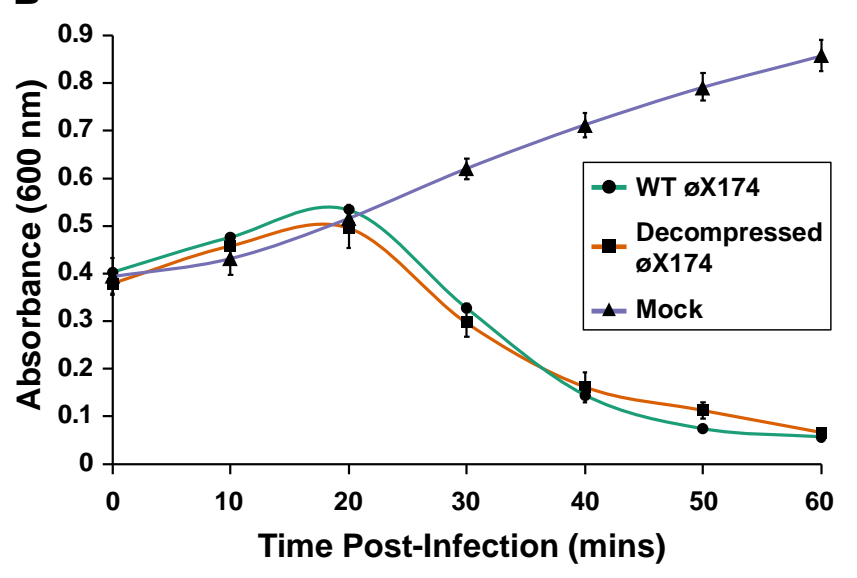

Figure 2: Decompressed $\phi X 174$ lyses host at similar efficiency to wild-type $\phi X 174$ at high multiplicity of infections but has reduced fecundity overall. (A) Double-agar overlay plates of wild-type $\phi \times 174$ and decompressed $\phi X 174$ infecting host $E$. coli C122(pJ804(Gene F)). Wild-type $\phi X 174$ plates contained 2 mM glucose and decompressed $\phi X 174$ plates contained $2 \mathrm{mM}$ rhamnose. Plate diameter $=85 \mathrm{~mm}$. (B) Lysis curve at multiplicity of infection $(\mathrm{MOI})=5$. Error bars represent one standard deviation $(n=2-3)$.

The significant burst-size deficiency in decompressed $\phi X 174$ is the likely reason for the small plaque size in this engineered phage (Figure 2A). Poor lysis is not the reason for altered 
burst-size in decompressed $\phi \mathrm{X} 174$ as lysis timing is not altered in a single-step growth experiment

(Figure 2B). Additionally, we removed all unattached phage before infection initiation in this assay, effectively excluding aberrant host attachment or recognition as the cause of this burst-size deficiency. We next assessed whether phage virion structure or genome ejection into cells could be the cause of the reduced burst-size. The decompressed $\phi \times 174$ genome encodes proteins with the same amino acid sequence as the wild-type $\phi \times 174$ genome, as such, we expect any structural changes to be either from disruption of the intimate genome-capsid interactions due to packaging a genome of different sequence or from inefficient assembly due to altered protein levels during capsid assembly.

\section{Decompressed $\varphi X 174$ virion has poor heat stability and attachment efficiency}

To identify whether decompressed $\phi \times 174$ virions are less stable than wild-type due to the differences in the packaged genome, we measured the effect of heat stress on phage infectivity. Samples of purified wild-type and decompressed $\phi X 174$ virions were subjected to $60^{\circ} \mathrm{C}$ over a range of times and the remaining infectivity was compared to untreated samples. Decompressed $\phi X 174$ virions were rapidly inactivated by the heat treatment after only 5-minutes, while wild-type \$X174 was slightly more infectious after this treatment (Figure 3A). A longer 15-minute treatment also significantly decreased decompressed $\phi X 174$ infectivity more than wild-type (Figure 3A).

This result indicates that the modularised genome of decompressed $\$ \times 174$ is having a negative effect on the thermal stability of the virion. This is not totally unexpected, as studies addressing heat stability of viral capsids with genomic variation have revealed different thermal stability between counterparts (Emerson, Arankalle et al., 2005, Ojosnegros, García-Arriaza et al., 2011, Saha, Wong et al., 2014). The physical properties of constituents within capsid shells (for example, salt ions and nucleotides) have been shown to directly influence a capsid's internal osmotic pressure, and consequently, mechanical stability (Evilevitch, Fang et al., 2008, Evilevitch, 
bioRxiv preprint doi: https://doi.org/10.1101/2020.06.10.143693; this version posted June 13, 2020. The copyright holder for this preprint (which was not certified by peer review) is the author/funder, who has granted bioRxiv a license to display the preprint in perpetuity. It is made available under aCC-BY-NC-ND 4.0 International license.

Lavelle et al., 2003, Ivanovska, Wuite et al., 2007, Roos, Bruinsma et al., 2010). So, while the decompressed $\phi \times 174$ genome encodes for the same genes and proteins, and is of the same absolute nucleotide length as the wild-type, it is reasonable to suggest that genome organisation is critical to maintaining thermal stability by maintaining optimal internal pressure and internal capsid interactions. Genome modularisation and the resulting alterations to the genome secondary structure (Appendix Figure S2) could alter the electrostatic interactions within the capsid (Belyi \& Muthukumar, 2006, Erdemci-Tandogan, Wagner et al., 2014, Šiber, Božič et al., 2012) therefore directly influencing capsid rigidity. These complex interactions and their impact on particle stability and genome packaging, have been observed before in other viruses (Bauer, Li et al., 2015, Mateo, Luna et al., 2008, Ojosnegros et al., 2011, Snijder, Uetrecht et al., 2013).

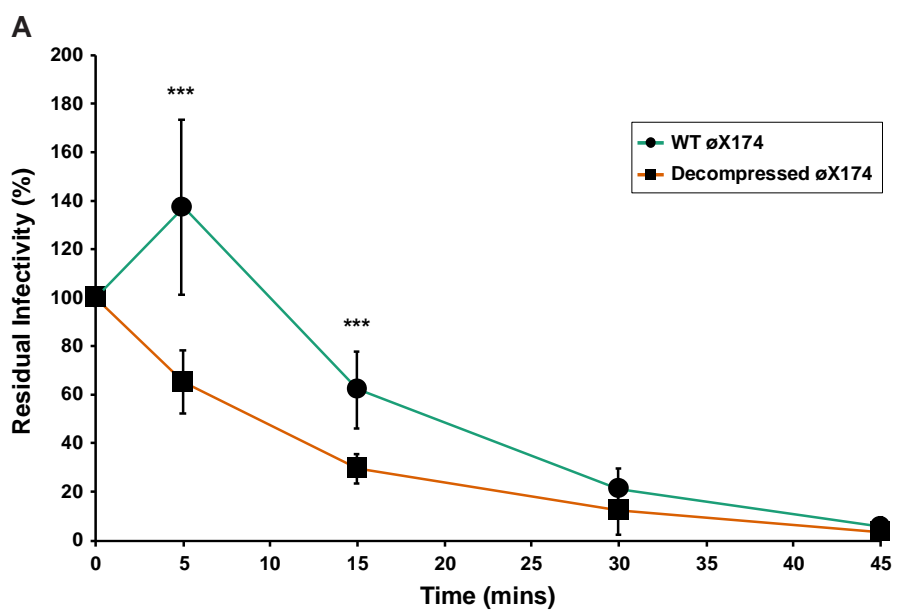

B

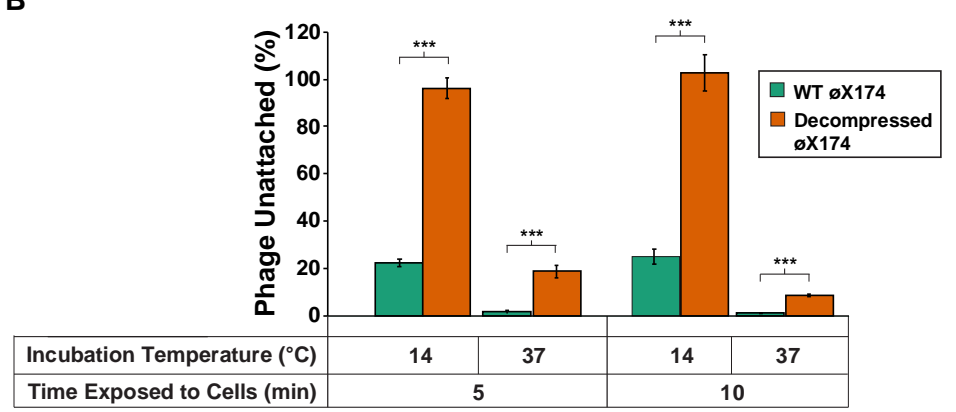

Figure 3: Decompressed $\phi X 174$ is both less heat stable and poorer at attaching to host cells than wildtype $\phi X 174$. (A) Heat stability of phage. Samples of decompressed $\phi X 174$ and wild-type $\phi X 174$ virus were exposed to heat stress $\left(60^{\circ} \mathrm{C}\right)$ for $5,15,30$, and 45 -minutes followed by measurement of residual infectivity by double-agar plate plaque enumeration. Error bars represent one standard deviation $(n=9)$. ${ }^{* *} p$-value $<1.0 \times 10^{-4}$. (B) Viral attachment assay. Lysis resistant $E$. coli C900 $\triangle$ slyD cells were incubated at the specified temperature with either wild-type $\phi X 174$ or decompressed $\$$ X174 phage for either 5 or 10minutes followed by enumerating unattached phage using the double-agar overlay method. Error bars represent one standard deviation $(n=4)$. ${ }^{* * *} p$-value $<1.0 \times 10^{-4}$. 
Given the lower thermal stability of the decompressed $\phi X 174$ virion we next measured the attachment efficiency to determine virion host-recognition and subsequent attachment. Attachment for wild-type and decompressed $\phi \times 174$ was measured at $14{ }^{\circ} \mathrm{C}$ and $37^{\circ} \mathrm{C}$. At $14{ }^{\circ} \mathrm{C}$ in starvation buffer $\phi X 174$ adsorbs to the host cell without undergoing eclipse (irreversible structural change) (Denhardt \& Sinsheimer, 1965, Newbold \& Sinsheimer, 1970c). This characteristic of $\phi X 174$ is particularly advantageous as it allows for the synchronisation of infection. In contrast, at $37^{\circ} \mathrm{C}$ in starvation buffer $\phi \times 174$ undergoes an irreversible structural change leading to the partial ejection of the genome (Newbold \& Sinsheimer, 1970c).

The results of the attachment assay at $14{ }^{\circ} \mathrm{C}$ showed that decompressed $\phi \times 174$ virions could not remain stably attached to host cells, as opposed to wild-type $\phi X 174$ that had $77.8 \%$ ( \pm $1.6 \%$ ) virions remaining attached after incubation with hosts for 5 minutes (Figure 3B). At $37^{\circ} \mathrm{C}$ decompressed $\phi X 174$ virions attach more stably to host cells, with $81.3 \%$ ( $\pm 2.7 \%)$ left attached, but was still significantly less than wild-type under the same conditions ( $91.5 \%( \pm 0.6 \%), p$-value $=$ $0.00004)$. Longer 10-min incubations did not substantially improve relative decompressed $\phi \times 174$ attachment (Figure 3B). These attachment assay results suggest that decompressed $\phi X 174$ virions can recognise the host cell receptor, as they are able to remain stably attached at $37^{\circ} \mathrm{C}$ and eclipse, but at $14^{\circ} \mathrm{C}$, pre-eclipsed decompressed $\phi X 174$ does not remain stably adsorbed to the host.

Together, these results provide evidence that the packaged genome of decompressed фX174 is impacting the properties of the virion, which in turn impairs attachment. Zeng, et al. (2017), measured the mechano-chemical properties of adeno-associated virus 2 and brome mosaic virus with different genomic cargo. They found that adding exogenous genetic material to these viral genomes has an influence on virus-substrate adhesion interactions with differing deformation and strong orientation biases for adsorption depending upon the genomic content (Zeng, Moller-Tank et al., 2017b). Further work by this group (Zeng, Hernando-Perez et al., 2017a) 
has illuminated the capsid orientation bias and deformity arising from adsorption in the structurally similar brome mosaic virus. The orientation bias as a result of the deformity of the capsid to maximise contact area would involve compressing the capsid inner surface and extending the outer surface (Zeng et al., 2017a), actions that will be impacted by properties of the encapsulated genome (Zeng et al., 2017b). As reflected by the attachment assay results, these mechano-chemical properties are likely perturbed in the decompressed $\phi X 174$ virion. To further support the notion that the genome-capsid interactions have profound effects on the dynamic function of virions, previous work in $\phi \times 174$ has shown that altering the internal capsid environment through mutant J proteins also alters attachment efficiency (Bernal, Hafenstein et al., 2004, Hafenstein \& Fane, 2002, Hafenstein, Chen et al., 2004). Additionally, altering the packaged genome sequence was also found to have profound effects on capsid biophysical properties (Hafenstein \& Fane, 2002). These studies, along with our experiments, suggest that the genome of the decompressed $\phi X 174$ virion is influencing the structural integrity and surface properties of the capsid, leading to perturbation of pre-eclipse attachment and capsid heat stability. To our knowledge, this study demonstrates for the first time that native gene architecture is critical for optimal capsid function.

Decompressed $\varphi X 174$ capsid morphology is identical to wild-type

To identify any major structural aberrations in the decompressed $\phi X 174$ capsid that may be causing the decreased attachment efficiency, we incubated purified virions with either DNase I or proteinase $\mathrm{K}$ and measured changes to viability. The results of this assay revealed that decompressed $\phi \times 174$ virions are slightly more stable under protease stress than wild-type ( $p$ value 0.0173$)$, but there was no significant difference under DNase I treatment, thereby making altered capsid permeability or partial genome ejection unlikely (Appendix Figure S3). 
bioRxiv preprint doi: https://doi.org/10.1101/2020.06.10.143693; this version posted June 13, 2020. The copyright holder for this preprint (which was not certified by peer review) is the author/funder, who has granted bioRxiv a license to display the preprint in perpetuity. It is made available under aCC-BY-NC-ND 4.0 International license.

To characterize subtler variations in capsid structure between wild-type and decompressed $\phi X 174$ we used cesium chloride $(\mathrm{CsCl})$ gradient purification to isolate virions and examined them by transmission electron microscopy (TEM). Visualisation and subsequent 2D-classification of wildtype and decompressed $\phi \times 174$ virions revealed no observable capsid morphology differences (Figure 4). Additionally, the diameter of both decompressed and wild-type virions was measured to be $33 \mathrm{~nm}$, in close agreement with wild-type measurements in other studies (McKenna, Xia et al., 1992, Sun, Roznowski et al., 2017, Yazaki, 1981). As no gross structural deformities were observed with the decompressed virion, we hypothesize that the mechanical properties of the capsid have been altered due to the packaging of the decompressed genome, thereby producing altered thermal stability and attachment issues (Figure 3).

A) $\mathrm{CsCl}$ gradient

B) TEM
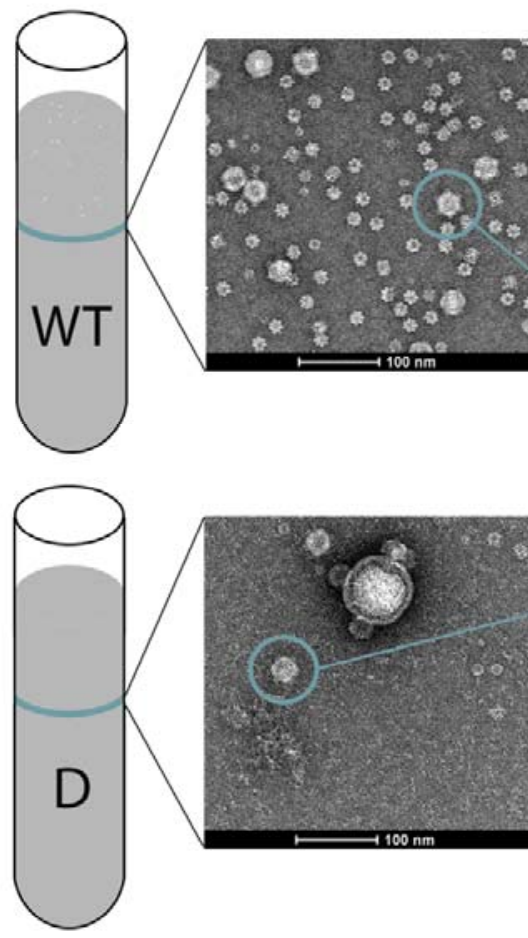
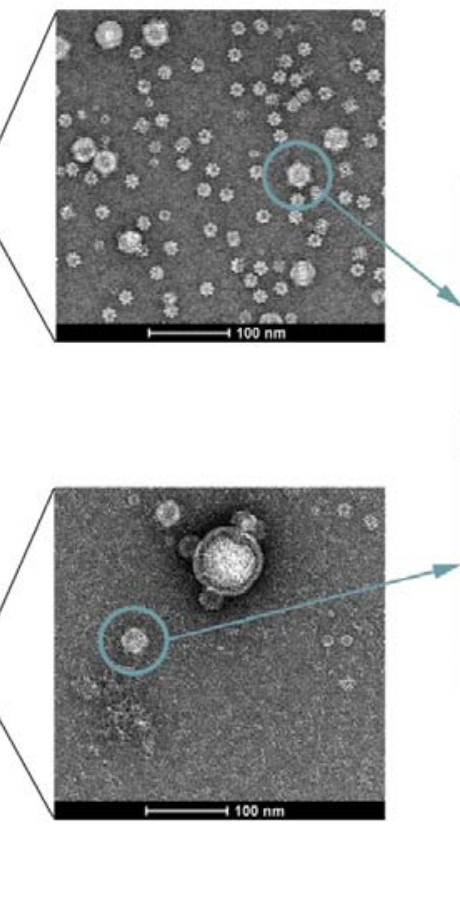

C) $2 \mathrm{D}$ class average

D) Overlay

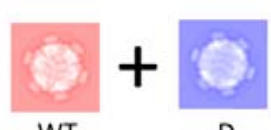

D
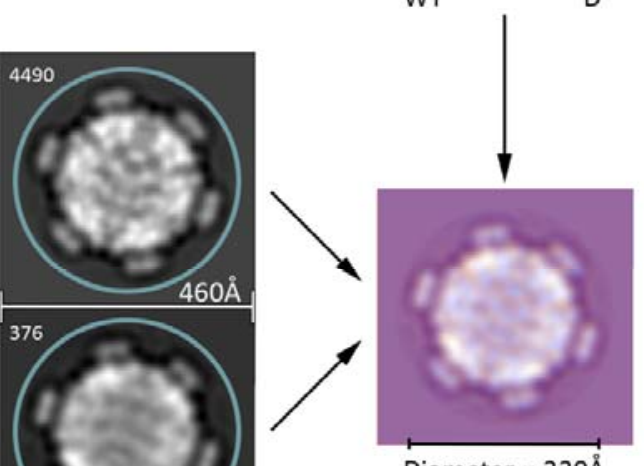

Diameter $=330 \AA$

Figure 4: Decompressed $\phi X 174$ and wild-type $\phi X 174$ virion morphologies are indistinguishable. (A) Phage band isolated after $\mathrm{CsCl}$ step-gradient ultracentrifucation. WT = wild-type and $\mathrm{D}=$ Decompressed $\phi \times 174$. (B) Uranyl-acetate negative stained particles visualised using transmission electron microscopy (TEM). Phage particles found in both preparations (teal circle). (C) 2D class averaging of phage capsids highlighted in (B). 4490 particles averaged for the wild-type capsid, and 376 particles averaged for the decompressed $\phi X 174$. Additional classifications and particle information available as Appendix Figures S4 and S5. (D) 2D class averaged images of capsids overlayed reveal no obvious morphology differences between wild-type $\phi X 174$ and decompressed $\phi \times 174$. 
Curiously, we also observed E. coli chaperone complex GroEL structures mixed with $\phi X 174-$ containing $\mathrm{CsCl}$ bands (Appendix Figure S4). As many viruses rely on host cellular chaperones to mediate their protein folding (Geller, Taguwa et al., 2012, Mayer, 2005, Xiao, Wong et al., 2010), including GroEL (Bouvaine, Boonham et al., 2011, Ding, Duda et al., 1995, Hanninen, Bamford et al., 1997), the co-purification of this large protein complex is not surprising, but has never been associated with $\phi X 174$-infections before.

Targeted proteomics reveals decompressed $\varphi \times 174$ infections initiate protein production earlier than wild-type

To identify whether there are any defects in phage protein production that could explain the decompressed $\phi \times 174$ reduced burst-size, we quantified the level of individual $\phi \times 174$ proteins produced during infection of the E. coli host. We infected E. coli C122(pJ804(Gene F)) with either wild-type or decompressed $\phi \times 174$ phage at $\mathrm{MOI}=1.2$ and captured samples over a time-course. Proteins from four post-infection time-points $(0,15,25$, and 35-minutes) were extracted and analysed by parallel reaction monitoring mass spectrometry (PRM) (Peterson, Russell et al., 2012). PRM is a targeted mass spectrometry acquisition method that enables highly sensitive and reproducible measurements of pre-determined peptide ions (Peterson et al., 2012), and was therefore a well-suited analytical method for quantitation of phage proteins in vivo. This approach successfully detected and quantified the relative abundance of phage proteins from within the dynamic background of the E. coli proteome, enabling comparative analyses of the wild-type and decompressed $\phi X 174$ phage proteomes across the infection cycle. For quantitation, each phage protein was measured using at least two peptides (except for proteins $\mathrm{K}, \mathrm{J}$, and $\mathrm{E}-$ where only one tryptic peptide was suitable (Appendix Dataset S1)).

Using PRM we observed viral protein expression in the decompressed $\phi X 174$ samples at time point 0-minutes (Figure 5 and Appendix Figures S6 and S7). Immediate expression was 
observed for all proteins except A, B, C, and K. The F protein was constitutively expressed from plasmid pJ804(Gene F). In contrast, proteins produced from wild-type $\phi X 174$ were not observed until at least 15-minutes post-infection (Figure 5). This surprising result is in contrast to previous literature that showed infection synchronisation conditions (incubation with cells at $<19^{\circ} \mathrm{C}$ and in starvation buffer) completely inhibited wild-type $\phi X 174$ eclipse and DNA ejection phases (Denhardt \& Sinsheimer, 1965, Newbold \& Sinsheimer, 1970b, Newbold \& Sinsheimer, 1970c). Therefore, this could indicate that decompressed $\phi X 174$ phage possessed some altered infection dynamics under the cold starvation conditions (Material and Methods). Temperature sensitive mutants of $\phi X 174$ have been shown to exhibit altered eclipse and DNA injection characteristics (Dalgarno \& Sinsheimer, 1968, Dowell, 1967, Ilag \& Incardona, 1993, Incardona, 1974), possibly as a result of structural changes (Dalgarno \& Sinsheimer, 1968, Dowell, 1967, Ilag \& Incardona, 1993), and may be evidenced by altered thermal stability of the phage virions (Dalgarno \& Sinsheimer, 1968, Dowell, 1967). The viral protein present at time point 0-minutes (Figure 5) and lower heat stability (Figure $3 \mathrm{~A}$ ) together show altered properties of the decompressed $\phi \times 174$ capsid, likely as a result of the decompressed genome packaged therein.

Proteomics reveals decompressed $\varphi X 174$ infection is deficient in proteins $B$ and $C$, whilst protein $A^{*}$ is overexpressed

Next we determined whether any $\phi X 174$ proteins (Appendix Table 1) produced during the infection cycle were altered between wild-type and decompressed $\phi X 174$. Two-factor ANOVA analysis was performed on each peptide with independent variables set to time and phage strain. The results of this analysis showed there were significant alterations in the expression of proteins $A^{*}, B, C, E, F$, and $H$ during decompressed $\phi X 174$ infection (Figure 5, Appendix Datasets S1 and S2). 

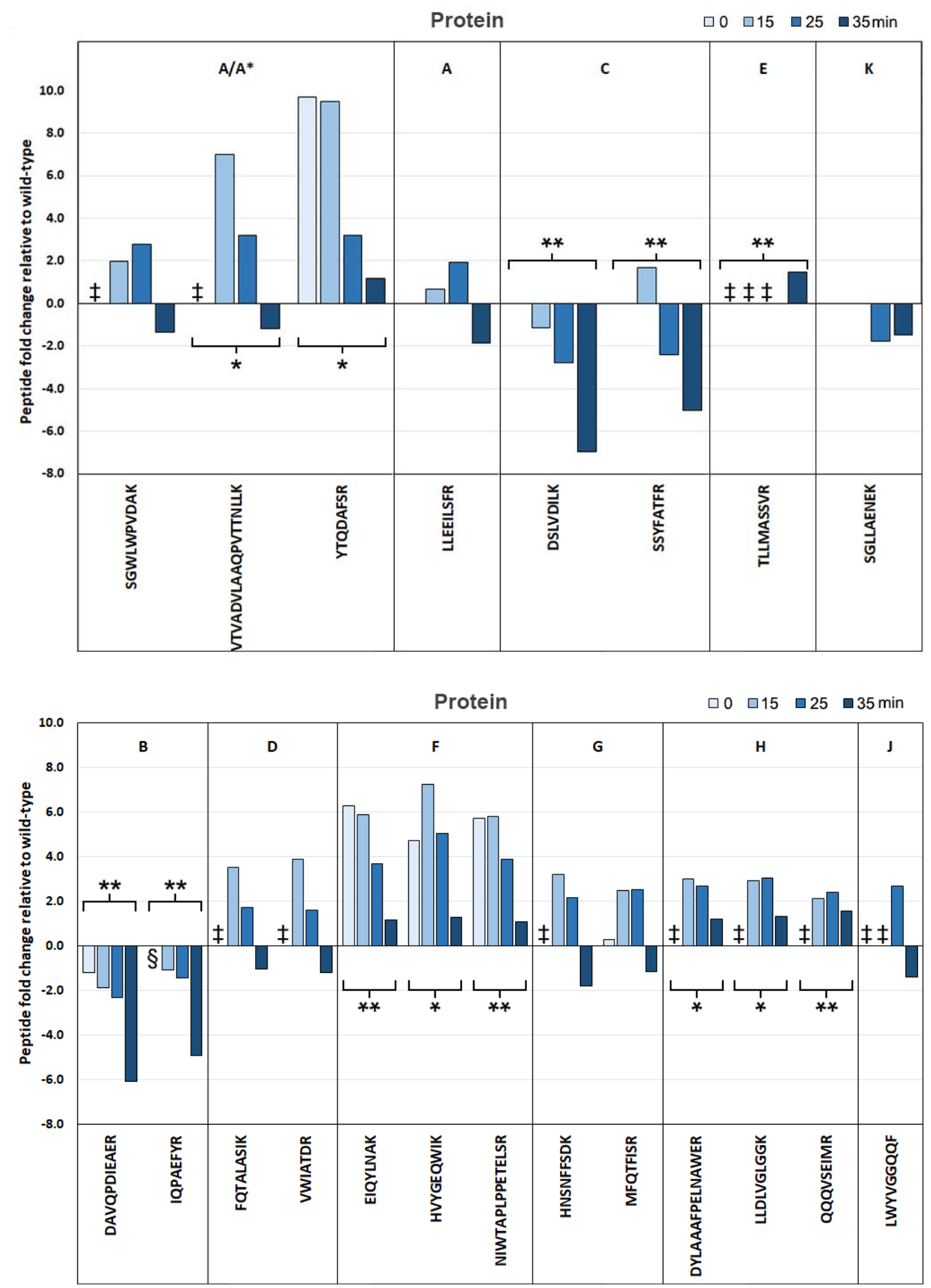

Figure 5: Mass spectrometric quantification of $\phi \times 174$ proteins produced during infection shows altered expression levels of proteins involved in genome replication and capsid packaging and assembly in decompressed $\phi X 174$. PRM quantification of targeted viral peptides across four time-points comparing decompressed relative to wild-type. (Top) Fold-change of peptides from replication associated proteins. (Bottom) Fold-change of peptides from capsid associated proteins. $\neq=$ Peptide detected in decompressed $\phi \times 174$ but not in the wild-type $\phi \times 174, \S=$ Peptide detected in wild-type $\phi \times 174$ but not in the decompressed $\phi X 174$. Two-factor ANOVA significance $*$-value $<0.05 . * *$-value $<0.005$. 
The lysis protein E was produced at high levels in decompressed $\phi \mathrm{X} 174$ across all time points relative to the wild-type (Figure 5). In contrast, in wild-type $\phi X 174$, protein E was only detectable at 35-minutes post-infection (Appendix Figure S6). This result is unexpected, as we measured lysis time of decompressed $\phi X 174$ as comparable to that of wild-type at $\mathrm{MOI}=5$ (Figure 2B) and therefore expected this protein's production to be similar between the strains in the proteomics experiment. Premature lysis or damage to the host cell as a result of expression of the lysis protein would most certainly impact viral infection fidelity as progeny production would be interrupted. Constant protein E expression from decompressed $\phi \times 174$ during infection indicates that the modularisation of the genome may have modified the lysis protein $\mathrm{E}$ regulation from wildtype, resulting in leaky expression. The gene for protein E was originally completely encoded within gene $D$, and thus modularisation has resulted in the E gene being moved 296 nucleotides downstream from its original site within $\phi X 174$ transcripts (Figure 6).

In contrast to protein $\mathrm{E}$, we found protein $\mathrm{C}$ expression was significantly diminished in the decompressed $\phi X 174$ infection (Figure 5). In the wild-type genome, gene $\mathrm{C}$ has significant levels of upstream sequence overlap with gene $\mathrm{K}$ as well as an overlapping start-stop codon junction with genes $A / A^{*}$ (Figure 6). The modularisation of these junctions, resulting in a modified 5'-UTR region and removal of the $\mathrm{A} / \mathrm{C}$ overlap may be responsible for decreased protein $\mathrm{C}$ expression.

During $\phi X 174$ infections, protein $C$ is responsible for the shift from single-strand genome production seeding the generation of more dsDNA replicative forms (stage II) to the production of ssDNA genomes destined for packaging within capsids to assemble infectious virions (stage III) (Aoyama \& Hayashi, 1986, Doore, Baird et al., 2014). More specifically, protein C functions by competitively binding to the $\phi \times 174$ origin of replication with antagonistic partner, host protein single-strand binding protein (SSB) (Doore et al., 2014). If protein C binds, then a round of stage III DNA synthesis occurs in which the production of single-stranded genomic DNA occurs, followed by packaging into the viral procapsid (Aoyama \& Hayashi, 1986). If SSB protein binds, then stage II 
synthesis continues (Aoyama \& Hayashi, 1986). It is known that an increase in host SSB protein relative to protein $\mathrm{C}$ during stationary phase infection results in reduced plaque sizes (Doore et al., 2014). The 6-fold decreased expression of protein C at 35-minutes post-infection likely results in a reduced ability to transition from stage II to stage III DNA synthesis and less efficient packaging of ssDNA genomes into available procapsids. Our observation of reduced protein C may also explain the reduced burst and plaque sizes for decompressed $\phi X 174$ (Figure 2A).

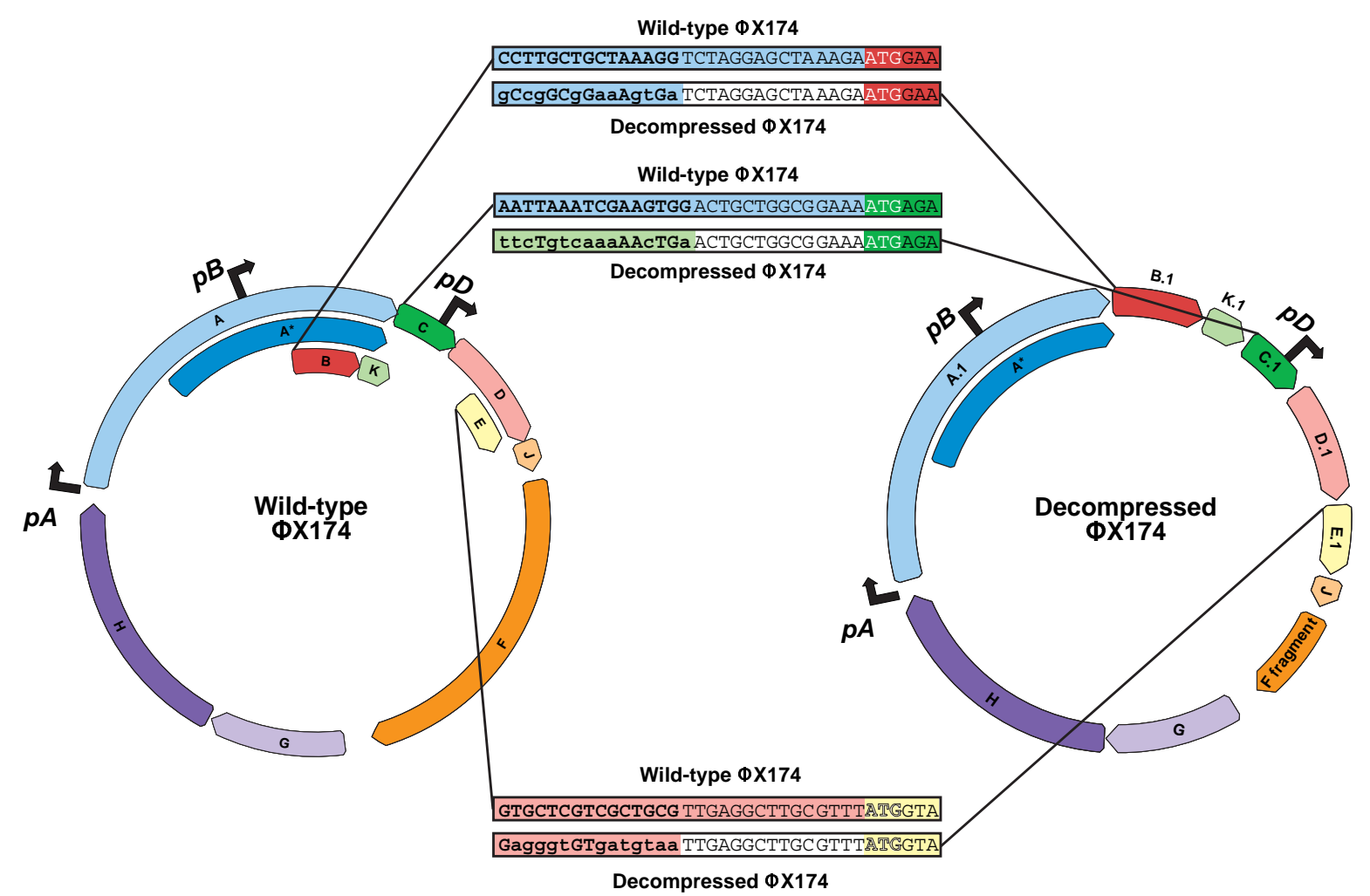

Figure 6: The heavily modified 5'-UTR of genes B, C, and E in the decompressed $\phi X 174$ genome may result in altered protein expression. Gene $B, C$, and $E$ sequences in the wild-type and decompressed $\phi X 174$ genomes are highlighted (boxed) and show the region 5' of the start codons (white bolded ATG text). Colored background to text indicates which gene the sequence belongs to: gene A (light blue), gene $\mathrm{K}$ (light green), gene C (dark green), gene D (pink), gene E (yellow), no gene (white). Wild-type gene C ATG start codon overlaps with gene A TGA stop codon. Bolded text and lower case nucleotides show positions in the 5 '-UTRs of decompressed $\phi X 174$ genes that differ from wild-type sequence.

We also found that protein $A^{*}$ was significantly upregulated during decompressed $\phi X 174$ infections. Although protein $A$ and $A *$ share $100 \%$ sequence identity, we were able to discriminate between protein $A$ and $A^{*}$ production through the measurement of the unique A peptide, 
LLEEILSFR. By comparing LLEEILSFR levels to three other peptides shared by proteins $A$ and $A *$ we observed that protein $A^{*}$ is highly upregulated while protein $A$ is not (Figure 5 ).

Protein $A^{*}$ controls the delicate balance between packaging and replication during $\phi \times 174$ infections (Roznowski, Doore et al., 2019). This function is accomplished through binding within the J-F intergenic region of the $\phi \times 174$ genome. This $A^{*}$ binding leads to inhibiting DNA unwinding in this region and disruption of protein A rolling circle genome amplification (Eisenberg \& Ascarelli, 1981, Roznowski et al., 2019, van Mansfeld, van Teeffelen et al., 1986). Therefore stochiometry differences between proteins $A$ and $A^{*}$ brought about by $A^{*}$ upregulation in decompressed $\phi \times 174$, are likely to cause issues with genome replication and the maintenance of genome packaging fidelity.

Protein B is an essential internal scaffolding protein that is needed for the assembly of the procapsid, an intermediary capsid particle devoid of the phage genome (Dokland, McKenna et al., 1997, Novak \& Fane, 2004, Siden \& Hayashi, 1974). We also find significantly reduced internal scaffolding protein B production in the decompressed $\phi X 174$ infection (Figure 5), pointing towards another potential reason for reduced viral plaque and burst-size (Figure 2A). A lack of internal scaffolding protein B would prevent intermediary assembly particles, $9 S$ and $6 S$, from forming $12 S$ particles (Novak \& Fane, 2004), thereby stalling productive virion assembly (Novak \& Fane, 2004).

In the decompressed $\phi X 174$ genome gene $B$ has been moved from its nested position within genes $A / A^{*}$ to a fully separated and downstream position (Figure 6). Furthermore, the gene B 5'-UTR region is identical up to 15 nucleotides $5^{\prime}$ of the gene B start codon but further upstream is completely different (Figure 6) and may be a factor for its reduced protein output.

To understand possible reasons for the large differences in protein expression between decompressed and wild-type $\phi \times 174$, we analysed mRNA folding across gene 5' termini and entire coding sequences (Appendix Figure S8) as well as host codon adaptability (Appendix Figure S9). Other work focused only on synonymous codon changes within $\phi X 174$ had found correlations 
between gene mRNA folding energy and codon adaptation index (CAI) (Jaschke, Dotson et al., 2019, Van Leuven, Ederer et al., 2020). In contrast, our analyses showed that neither predictive mRNA structure or codon usage bias differences explain the difference in protein production between the strains, further emphasising our current inability to accurately predict the effects of large-scale genome architectural changes.

\section{Conclusion}

Re-engineering and recapitulating natural genes and gene pathways of interest is now enabling researchers in synthetic biology to create genomes with novel configurations never before seen in natural systems. However, our understanding of the intricacies of genome architecture, such as the functional importance of overlapping genes, is still lacking.

In this study, we have revealed the biological ramifications of whole genome modularisation in the model virus $\phi X 174$. For the first time, using the fully refactored $\phi X 174$ and careful phenotypic and targeted proteomic measurements, we have conclusively demonstrated that removing coding overlap causes major defects in protein expression and reproduction efficiency. More specifically, we show that the decompressed $\phi X 174$ infection cycle has altered protein expression for 5 of the 11 ( $\sim 5 \%$ ) phage proteins ( $A^{*}, B, C, E$, and $H$ ), as well as perturbed burst-size, capsid stability, and host-cell attachment. This work provides key evidence that gene overlap is a crucial feature in genomes and points at a direct mechanism for their retention during evolutionary selection. Lastly, our work shows that in order to retain the highest fitness levels possible, conserving overlapped gene topologies should be strongly considered in genome engineering projects going forwards. 


\section{MATERIALS AND METHODS}

Strains

Phage strains $\phi X 174$ and $\phi X 174.1 f$ (termed decompressed $\phi X 174$ throughout) were used throughout this work (Jaschke et al., 2019, Jaschke et al., 2012). The host strain used for experiments and virus propagation (unless stated otherwise) was E. coli C122 (Public Health England NCTC122) which carried a plasmid pJ804(Gene F) containing the $\$$ X174 gene F (Genbank No. NC_001422.1) under a rhamnose-inducible promoter (Jaschke et al., 2012). Growth of the host strain was conducted at $37^{\circ} \mathrm{C}, 250$ RPM (with $25 \mathrm{~mm}$ orbital shaking) in LB Miller broth (10 $\mathrm{g} / \mathrm{L}$ tryptone, $10 \mathrm{~g} / \mathrm{L} \mathrm{NaCl}$, and $5 \mathrm{~g} / \mathrm{L}$ yeast extract) containing $50 \mu \mathrm{g} / \mathrm{mL}$ carbenicillin and $2 \mathrm{mM}$ $\mathrm{CaCl}_{2}$ and either $2 \mathrm{mM}$ rhamnose for decompressed $\phi X 174$ or $2 \mathrm{mM}$ glucose for wild-type $\phi X 174$.

Phage infection

Infections with either the wild-type or decompressed phage were conducted by first growing the host strain overnight ( 18 -hours) followed by subculturing the cells $1 / 100$ in fresh LB broth (Miller) containing $50 \mu \mathrm{g} / \mathrm{mL}$ carbenicillin and $2 \mathrm{mM}$ calcium chloride, and growing until an O.D of $0.5-0.6$. The cells were then pelleted $\left(4,000 \mathrm{RCF}, 14^{\circ} \mathrm{C}, 8\right.$-minutes), and subjected to two wash and pellet cycles with ice-cold HFB buffer (60 mM ammonium chloride, $90 \mathrm{mM}$ sodium chloride, $100 \mathrm{mM}$ potassium chloride, $1 \mathrm{mM}$ magnesium sulfate, $1 \mathrm{mM}$ calcium chloride, and 100 $\mathrm{mM}$ tris base, $\mathrm{pH}$ 7.4). After which the cell pellet was resuspended to $1 / 10$ of the original culture volume using ice-cold HFB followed by addition of virus at required $\mathrm{MOI}$. The cell-virus mixture was left at $14^{\circ} \mathrm{C}$ for 30 -minutes to allow viral attachment (infection synchronisation) (Newbold \& Sinsheimer, 1970 a). Infection initiation was triggered by addition of pre-warmed $\left(37^{\circ} \mathrm{C}\right)$ LB broth (Miller) containing $50 \mu \mathrm{g} / \mathrm{mL}$ carbenicillin and $2 \mathrm{mM} \mathrm{CaCl}_{2}$ (and either $2 \mathrm{mM}$ rhamnose or glucose) to a final volume constituting original culture volume. 


\section{Phage isolation and purification}

Phage stocks were produced through two methods. Both involved growth of $800 \mathrm{~mL}$ of $E$. coli $\mathrm{C} 122(\mathrm{pJ} 804(G e n e \mathrm{~F})$ ) culture to mid-log, as described. If propagation of decompressed $\phi \mathrm{X} 174$ was required, the media included $50 \mu \mathrm{g} / \mathrm{mL}$ carbenicillin and $2 \mathrm{mM}$ rhamnose. Virus was spiked into the culture and allowed to propagate until culture clearance. The first method, involved pelleting of cleared cultured to remove bacterial debris (4,000 RCF for 8-minutes). The supernatant was retained and filtered using Amicon Ultra-15 Centrifugal Filter Units (Merck, Germany) with a 100 kDa molecular weight cut-off. The second method was for ultra-pure phage stocks. After culture clearance, $\mathrm{NaCl}$ was added to a final concentration of $1 \mathrm{M}$, cooled to $4^{\circ} \mathrm{C}$, followed by pelleting of bacterial debris (4,000 RCF for 8-minutes) and retaining the supernatant and addition of poly-ethylene glycol (PEG) 8000 to a final concentration of $15 \%(w / v)$. The supernatant was stored overnight ( 18 -hours) at $4^{\circ} \mathrm{C}$, followed by pelleting the phage at $4,000 \mathrm{RCF}$ for 8-minutes. Phage pellets were resuspended in HFB buffer and PEG 8000 was removed using three wash cycles of equal volume chloroform. Finally, the phage was $\mathrm{CsCl}$ step-gradient purified using $\mathrm{CsCl}$ density steps of $1.30 \mathrm{~g} / \mathrm{mL}, 1.40 \mathrm{~g} / \mathrm{mL}$, and $1.50 \mathrm{~g} / \mathrm{mL}$ using the Beckman Coulter SW32Ti swinging bucket rotor at 32,000 RPM for 16 -hours at $10^{\circ} \mathrm{C}$. Phage bands were removed, and buffer-exchanged using the Amicon Ultra-15 Centrifugal Filter Units (Merck, Germany) with a 100 kDa molecular weight cut-off in HFB buffer. The titre for viral stocks was determined using the double-agar overlay method (Kropinski, Mazzocco et al., 2009). Soft agar was supplemented with $50 \mu \mathrm{g} / \mathrm{mL}$ carbenicillin and $2 \mathrm{mM}$ rhamnose for enumeration of the decompressed $\phi X 174$ phage titre.

\section{Genome folding prediction}

Minimum free energy (MFE) secondary structure predictions for decompressed and wildtype $\phi X 174$ were performed through the ViennaRNA websuite's RNAfold server (Lorenz, Bernhart 
et al., 2011). Default settings were used, except for energy parameters which were set as DNA parameters.

mRNA Structure Predictions

RNA folding simulations were performed on an 83-nt window around the start codon of each gene using the Nucleic Acid Package (NUPACK) web server with default settings (Zadeh, Steenberg et al., 2011), or using the entire coding sequence using mfold web server with default settings (Zuker, 2003). Lowest-energy structures were reported.

\section{Bacteriophage lysis curve measurements}

Lysis curve for decompressed and wild-type $\phi X 174$ was conducted in parallel $10 \mathrm{~mL}$ triplicate cultures, and grown and synchronised as previously described. $2 \mathrm{mM}$ rhamnose was added to decompressed $\phi X 174$ cultures to induce gene $\mathrm{F}$ on $\mathrm{pJ} 804$ (Gene $\mathrm{F}$ ), and $2 \mathrm{mM}$ glucose to wild-type cultures to suppress the induction of the plasmid-borne gene F. Culture samples for O.D measurements were taken every 10 -minutes for 60 -minutes. PCR was performed on cultures at the end of the experiment to confirm there was no cross-contamination of phage strains (Appendix Figure S1).

\section{Bacteriophage attachment}

Cultures were grown as described, except, lysis resistant $E$. coli $C 900(\Delta s / y D)$ which contains a mutation conferring resistance to $\phi \times 174$ E-mediated lysis (Roof, Horne et al., 1994) was used as the host cell for attachment (a gift from Bentley A. Fane). At mid-log, cells were pelleted, washed and resuspended in microcentrifuge tubes to $1 / 10^{\text {th }}$ of the original culture volume with HFB buffer that was either pre-cooled for the $14^{\circ} \mathrm{C}$ assay, or pre-warmed for the $37^{\circ} \mathrm{C}$ assay. Phage stock was then added to the cells, followed by incubation at the required temperature with continuous 
culture agitation at 900 RPM using a benchtop heating block with Eppendorf holding cassette. At

5-minutes and 10-minutes post-incubation, cells were immediately pelleted at 4,000 RCF for 5minutes, followed by removal of the top $100 \mu \mathrm{L}$ of the supernatant for assessment of viral titre using the double-agar overlay method.

\section{Bacteriophage progeny production measurements}

Cultures and infection synchronisation was performed as described, except, virus was added to a final $\mathrm{MOI}$ of 0.01 . After synchronisation, cells were pelleted and the supernatant was retained for titre. Cultures were then re-suspended using pre-warmed $\left(37^{\circ} \mathrm{C}\right) \mathrm{LB}$ with $2 \mathrm{mM} \mathrm{CaCl}_{2}$ and $50 \mu \mathrm{g} / \mathrm{mL}$ carbenicillin, and supplemented with either $2 \mathrm{mM}$ glucose for the wild-type virus, or $2 \mathrm{mM}$ rhamnose for the decompressed phage. Resuspended cultures were then diluted with media according to pre-determined levels to allow for appropriate enumeration of plaques. Cultures were then incubated at $37^{\circ} \mathrm{C}$ with 250 RPM agitation for 40 -minutes with sampling of the culture at $5,10,15,20,25,30,35$, and 40-minute time-points. Sampling involved removing $200 \mu \mathrm{L}$ of the culture and immediately mixing with $100 \mu \mathrm{L}$ of chloroform, followed by storage on ice. Samples were then spun at 5,000 RCF for 5-minutes, after which $100 \mu \mathrm{L}$ of the top layer was removed and put into a fresh tube. Assessment of viral titre was then performed using the doubleagar overlay method.

\section{Virion heat stability}

Phage stocks were diluted to approximately $10^{2} \mathrm{PFU} / \mu \mathrm{L}$ using LB broth (Miller) supplemented with $10 \%(\mathrm{v} / \mathrm{v})$ glycerol, and $2 \mathrm{mM}$ calcium chloride. Eppendorf tubes containing 90 $\mu \mathrm{L}$ of the same LB broth diluent as well as $10 \mu \mathrm{L}$ of the diluted phage stock. The tubes were individually labelled according to pre-determined harvest points of $0,5,15,30$, and 45 -minutes, with the 0-minute tube being placed immediately on ice. The rest of the tubes were incubated at 
$60^{\circ} \mathrm{C}$, and then placed upon ice when reaching their time point. Titres of the samples was performed as described using the double-agar overlay method.

\section{DNase I and proteinase K stability assays}

For both assays, individual plaques were stabbed from double-agar overlay plates and eluted into HFB buffer for the DNase I assay, or $10 \mathrm{mM}$ Tris-HCl for the proteinase $\mathrm{K}$ assay. The DNase I assay consisted of aliquoting $7.5 \mu \mathrm{L}$ of decompressed or wild-type plaque suspension into a $200 \mu \mathrm{L}$ capacity microcentrifuge tubes containing $0.5 \mu \mathrm{L}$ DNase I $(2,000 \mathrm{U} / \mathrm{mL})$ (or water (control)), $1 \mu \mathrm{L}$ DNase I buffer (10x) and incubated at $37^{\circ} \mathrm{C}$ for 1 -hour. The proteinase $\mathrm{K}$ assay consisted of aliquoting $9 \mu \mathrm{L}$ of plaque suspension into a $200 \mu \mathrm{L}$ capacity microcentrifuge tube and either $1 \mu \mathrm{L}$ of $1 \mu \mathrm{g} / \mu \mathrm{L}$ proteinase $\mathrm{K}$, or water (control) and incubated at $37^{\circ} \mathrm{C}$ of for 4 -hours. For both assays, plaques were enumerated through the double-agar overlay assay (Kropinski et al., 2009).

\section{Electron microscopy}

A $4 \mu \mathrm{L}$ solution of decompressed or wild-type $\phi X 174$ virions were applied to glowdischarged copper grids (carbon type B with formvar, 200 mesh (Ted Pella Inc., United States)), then stained with $2 \%$ uranyl acetate and dried at room temperature. The screening of the capsids was carried on FEI Tecnai G2 20 electron microscope (ThermoFisher Scientific, United States) at $200 \mathrm{kV}$ accelerating voltage. Data images for 2D classification of both capsids were automatically collected on a Talos Arctica transmission electron microscope operated at $200 \mathrm{kV}$ acceleration voltage using EPU software (ThermoFisher Scientific, United States). All datasets were collected on a Falcon III detector in linear mode at 92,000x magnification with a pixel size of $1.6 \AA$ per pixel. 
MotionCor2 (Zheng, Palovcak et al., 2017) was used to correct local beam-induced motion and to align resulting frames. Micrographs were then sorted on the basis of image quality, and 1,946 micrographs for wild-type \& 1,633 micrographs for decompressed $\phi X 174$ were used for subsequent reconstruction using RELION 3.0 beta (Fernandez-Leiro \& Scheres, 2017, Scheres, 2012b, Zivanov, Nakane et al., 2018). Particles (37,150 for wild-type \& 2,971 for decompressed $\phi X 174)$ were picked automatically from the full data set and extracted by using a box size of $300 \times$ 300 pixels. The particles were then analysed by 2D classification in RELION 3.0 beta.

\section{Cryo-electron microscopy}

A $4 \mu \mathrm{L}$ solution of co-isolated small particles were applied to glow-discharged copper grids (Quantifoil R2/2, Quantifoil Micro Tools), blotting for 3-seconds at $4{ }^{\circ} \mathrm{C}$ with $90 \%$ humidity and plunging into liquid ethane using a Lecia EM GP device (Leica Microsystems, Germany). Cryo-EM data were collected on a Talos Arctica transmission electron microscope operated at $200 \mathrm{kV}$ acceleration voltage using EPU automated data collection software (ThermoFisher Scientific, United States). All datasets were collected on a Falcon III detector in counting mode at 120,000x magnification with a pixel size of $1.25 \AA$ per pixel.

\section{Image processing and refinement}

MotionCor2 (Zheng et al., 2017) was used to correct local beam-induced motion and to align resulting frames. Defocus and astigmatism values were estimated using Gctf (Zhang, 2016). Micrographs were then sorted on the basis of image quality, and 1,424 micrographs were used for subsequent reconstruction using RELION 3.0 beta (Fernandez-Leiro \& Scheres, 2017, Scheres, 2012b, Zivanov et al., 2018). 1,000 particles from the data set were manually picked and subjected to 2D classification to generate templates for auto-picking. 72,212 particles were automatically picked and extracted by using a box size of $200 \times 200$ pixels. The particles were 
analysed by $2 \mathrm{D}$ classification, and 10 classes showing clear structural details were selected for further processing with 61,922 particles. The map at $20 \AA$ A generated from Protein Data Bank (2C7E) was used as an initial model for 3D classification. A subset of 23,517 particles was then used for the first round of 3D refinement, which results in a map with a resolution of $5.7 \AA$. The resolution was improved to $5.1 \AA$ A after doing post-processing (soft-edge masking and B-factor sharpening). 3D maps were post-processed to automatically estimate and apply the B-factor and to determine the resolution by Fourier shell correlation (FSC) between two independent half datasets using 0.143 criterion (Scheres, 2012a).

Label-free quantitative mass spectrometry - Parallel reaction monitoring (PRM)

E. coli C122(pJ804(Gene F)) was grown from overnight ( 18-hours) cultures to mid-log phase in LB broth (Miller) supplemented with $2 \mathrm{mM} \mathrm{CaCl}_{2}$ and $50 \mu \mathrm{g} / \mathrm{mL}$ carbenicillin. Cultures were then prepared for infection synchronisation with either decompressed or wild-type $\phi X 174$ strains at $\mathrm{MOI}=1.2$ (to the starved hosts, we added $230 \mu \mathrm{L}$ of LB broth (Miller) with $2 \mathrm{mM} \mathrm{CaCl}$ and $50 \mu \mathrm{g} / \mathrm{mL}$ carbenicillin containing phage at the appropriate PFU), as described earlier. After which, the infection was initiated by the addition of warm $\left(37^{\circ} \mathrm{C}\right) \mathrm{LB}$ broth (Miller) supplemented with $2 \mathrm{mM} \mathrm{CaCl}, 50 \mu \mathrm{g} / \mathrm{mL}$ carbenicillin and either $2 \mathrm{mM}$ rhamnose for the decompressed $\phi \times 174$ strain cultures, or glucose for the wild-type cell cultures. 0-minute time-points were collected immediately $(2.25 \mathrm{~mL})$ and placed on ice and then the cultures were incubated at $37^{\circ} \mathrm{C}, 250 \mathrm{RPM}$. At time-points 15, 25, and 35-minutes post-infection initiation, $2.25 \mathrm{~mL}$ of culture was harvested and stored on ice. Samples were pelleted, and washed twice with ice-cold HFB buffer, followed by storing the pellets at $-30^{\circ} \mathrm{C}$ overnight ( 18-hours).

The next day, sample pellets were resuspended in $200 \mu \mathrm{L}$ lysis buffer (100 mM triethylammonium bicarbonate buffer (TEAB) with $1 \%(\mathrm{v} / \mathrm{v})$ sodium deoxycholate $(\mathrm{SDC})$ and $1 \mathrm{x}$ protease inhibitor cocktail solution (Roche, Switzerland)), and subjected to probe sonication (30\% 
amplitude, 5 bursts). Reduction and alkylation of cysteine residues (dithiothreitol (DTT) to $10 \mathrm{mM}$, incubated at $60^{\circ} \mathrm{C}$ for 30 -minutes followed by iodoacetamide (IAA) to $30 \mathrm{mM}$, incubated 1-hour in the dark, and lastly, quenching with equal molarity of DTT), followed by chloroform-methanol protein precipitation to obtain pure protein pellets that were subsequently resuspended in digestion buffer (100 mM TEAB with $1 \%(\mathrm{v} / \mathrm{v})$ SDC) and quantified by the Pierce ${ }^{\mathrm{TM}}$ BCA Protein Assay Kit (ThermoFisher Scientific, United States). From each sample, $30 \mu \mathrm{g}$ of protein was taken for digestion with trypsin $(2 \%(\mathrm{w} / \mathrm{w}))$ (Promega, United States) and left overnight at $37^{\circ} \mathrm{C}(\sim 18-$ hours). After digestion, samples were acidified with $100 \%$ formic acid to $1 \%(\mathrm{v} / \mathrm{v})$ and SDC was removed by spinning samples at 20,000 RCF and collecting the supernatant into a fresh tube. Samples were then vacuum centrifuged and dry peptides were stored at $-30^{\circ} \mathrm{C}$ until ready for mass spectrometry analysis.

Peptides were reconstituted in $2 \%(\mathrm{v} / \mathrm{v})$ acetonitrile $(\mathrm{ACN})$ and $0.1 \%(\mathrm{v} / \mathrm{v})$ formic acid (buffer A) to a final concentration of $0.1 \mu \mathrm{g} / \mu \mathrm{L} .1 \mu \mathrm{g}(10 \mu \mathrm{L})$ of each sample was analysed on a QExactive mass spectrometer (ThermoFisher Scientific, United States) coupled to an EASY-nLC1000 system (ThermoFisher Scientific, United States). Peptide samples were injected onto the LC system using buffer $\mathrm{A}$ and were bound on a $75 \mu \mathrm{M} \times 100 \mathrm{mM}$ C18 HALO column ( $2.7 \mu \mathrm{M}$ bead size, $160 \AA$ pore size). A flow rate of $300 \mathrm{~nL} / \mathrm{min}$ using an increasing linear gradient of buffer $\mathrm{B}(99.9 \%(\mathrm{v} / \mathrm{v})$ acetonitrile, $0.1 \%(\mathrm{v} / \mathrm{v})$ formic acid) was run from $1 \%$ to $50 \%$ for 110 -minutes followed by $85 \%$ buffer B for 10-minutes.

An inclusion list was used to target pre-defined precursor mass-to-charge $(\mathrm{m} / \mathrm{z})$ (Appendix Dataset S3), and the mass spectrometer was operated to perform one full-ms scan (70000 resolution (at $400 \mathrm{~m} / \mathrm{z}$ ) across the $\mathrm{m} / \mathrm{z}$ range of $320-1800 \mathrm{~m} / \mathrm{z}$ ) with an automatic gains control (AGC) target of $1 \mathrm{e} 6$ (or a maximum fill time of $200 \mathrm{~ms}$ ), followed by sequential PRM scans using the inclusion list (loop count 39, isolation window of $2 \mathrm{~m} / \mathrm{z}$ ). The selected precursor ions from PRM scans had an AGC target of $1 \mathrm{e} 6$ and a maximum fill time of $58 \mathrm{~ms}$, after which, they were 
transferred from the C-trap to the higher energy collision dissociation (HCD) cell for fragmentation at a normalized collision energy of 27. MS/MS spectra were collected at a resolution of 17500 (at $400 \mathrm{~m} / \mathrm{z})$.

Raw files were analysed by MaxQuant version 1.6.10.43 (Cox \& Mann, 2008) against a \$X174 protein sequence list generated from GenBank file NC_001422.1. Cysteine carbamidomethylation was selected as a fixed modification and protein and peptide sequence match identifications were set at a $1 \%$ false discovery rate cut-off. Result files were imported and analysed in Skyline version 19.1.0.193 (MacLean, Tomazela et al., 2010), and peptides with less than 3 matching fragment ions were filtered out. The summed area values of all individual transitions for each precursor (total area) were extracted after applying Savitzky-Golay Smoothing and these values were used to quantify peptide relative abundance. The median total ion current (TIC) area across all samples was used for normalisation by correcting for injection amount. The median TIC was divided by the sample's TIC and the ratio of this was used to normalise the total transition area. Average and standard deviation of the total area were calculated across biological triplicates, constituting relative peptide (and by extension, protein) abundance. Statistical analysis was performed individually on each peptide and significance level was established using single or two-factor ANOVA where appropriate (significance $=p$-value $<0.05$ ). Fold-change was expressed using decompressed $\phi X 174$ average intensity over wild-type $\phi X 174$ average intensity.

\section{ACKNOWLEDGEMENTS}

We recognize that this research was conducted on the traditional lands of the Wattamattagal clan of the Darug nation. BWW was supported by a Macquarie Research Excellence PhD Scholarship, PRJ was supported by the Molecular Sciences Department, Faculty of Science \& Engineering, and the Deputy Vice-Chancellor (Research) of Macquarie University. JFR thanks the Cryo Electron Microscopy Facility through the Victor Chang Innovation Centre, funded by the NSW government, 
and the Electron Microscope Unit at UNSW, Sydney. We thank Dr. Pascal Steffen (The University of Sydney), Dr Roy Walker (Macquarie University), and Prof. Bentley Fane (University of Arizona) for helpful discussions and feedback, Dr. Chao Shen (Macquarie University) for assistance with microscopy. Aspects of this research were conducted at the Australian Proteome Analysis Facility.

\section{AUTHOR CONTRIBUTIONS}

BWW contributed Conceptualisation, Formal analysis, Investigation, Methodology, Visualisation, Writing - original draft, and Writing - review and editing. JR contributed Formal analysis, Investigation, Methodology, Resources, Validation, Visualization, Writing - original draft, and Writing - review \& editing. PRJ contributed Conceptualization, Funding acquisition, Project administration, Resources, Validation, Visualization, Writing - review \& editing, and Supervision. MPM contributed Conceptualization, Funding acquisition, Resources, Writing - review \& editing, Supervision.

\section{DATA ACCESS}

Raw and processed proteomics data generated in this study is available in the Panorama Repository under https://panoramaweb.org/phix174.url and ProteomeXchange under PXD019681.

\section{CONFLICT OF INTEREST}

The authors declare that they have no conflict of interest.

\section{REFERENCES}

Abedon ST, Culler RR (2007a) Bacteriophage evolution given spatial constraint. Journal of Theoretical Biology 248: 111-119 
Abedon ST, Culler RR (2007b) Optimizing bacteriophage plaque fecundity. J Theor Biol 249: 582-92

Aoyama A, Hayashi M (1986) Synthesis of bacteriophage [XX174 in vitro: Mechanism of switch from DNA replication to DNA packaging. Cell 47: 99-106

Baba T, Ara T, Hasegawa M, Takai Y, Okumura Y, Baba M, Datsenko KA, Tomita M, Wanner BL, Mori H (2006) Construction of Escherichia coli K-12 in-frame, single-gene knockout mutants: the Keio collection. Mol Syst Biol 2: 2006.0008-2006.0008

Bauer DW, Li D, Huffman J, Homa FL, Wilson K, Leavitt JC, Casjens SR, Baines J, Evilevitch A (2015) Exploring the Balance between DNA Pressure and Capsid Stability in Herpesviruses and Phages. Journal of Virology 89: $9288-9298$

Belshaw R, Pybus OG, Rambaut A (2007) The evolution of genome compression and genomic novelty in RNA viruses. Genome research 17: 000-000

Belyi VA, Muthukumar M (2006) Electrostatic origin of the genome packing in viruses. Proceedings of the National Academy of Sciences 103: 17174-17178

Bernal RA, Hafenstein S, Esmeralda R, Fane BA, Rossmann MG (2004) The phiX174 protein J mediates DNA packaging and viral attachment to host cells. J Mol Biol 337: 1109-22

Bouvaine S, Boonham N, Douglas AE (2011) Interactions between a luteovirus and the GroEL chaperonin protein of the symbiotic bacterium Buchnera aphidicola of aphids. Journal of General Virology 92: 14671474

Brandes N, Linial M (2016) Gene overlapping and size constraints in the viral world. Biology Direct 11: 26

Brantl S (2002) Antisense-RNA regulation and RNA interference. Biochimica et Biophysica Acta (BBA) - Gene Structure and Expression 1575: 15-25

Brown CJ, Stancik AD, Roychoudhury P, Krone SM (2013) Adaptive regulatory substitutions affect multiple stages in the life cycle of the bacteriophage []X174. BMC Evolutionary Biology 13: 66

Cavalli G, Misteli T (2013) Functional implications of genome topology. Nature Structural \& Molecular Biology 20: 290-299

Cecchini N, Schmerer M, Molineux IJ, Springman R, Bull JJ (2013) Evolutionarily stable attenuation by genome rearrangement in a virus. G3 (Bethesda) 3: 1389-97

Chan LY, Kosuri S, Endy D (2005) Refactoring bacteriophage T7. Mol Syst Biol 1: 2005.0018-2005.0018

Chen N, Stein LD (2006) Conservation and functional significance of gene topology in the genome of Caenorhabditis elegans. Genome Res 16: 606-617

Chirico N, Vianelli A, Belshaw R (2010) Why genes overlap in viruses. Proc Biol Sci 277: 3809-17

Chung W-Y, Wadhawan S, Szklarczyk R, Pond SK, Nekrutenko A (2007) A First Look at ARFome: Dual-Coding Genes in Mammalian Genomes. PLOS Computational Biology 3: e91

Cox J, Mann M (2008) MaxQuant enables high peptide identification rates, individualized p.p.b.-range mass accuracies and proteome-wide protein quantification. Nature Biotechnology 26: 1367-1372

Dalgarno L, Sinsheimer RL (1968) Process of infection with bacteriophage phiX174. XXIV. New type of temperature-sensitive mutant. Journal of virology 2: 822-829 
Dandekar T, Snel B, Huynen M, Bork P (1998) Conservation of gene order: a fingerprint of proteins that physically interact. Trends in Biochemical Sciences 23: 324-328

David CK (2000) Stability and evolution of overlapping genes. Evolution 54: 731-739

Davila Lopez M, Martinez Guerra JJ, Samuelsson T (2010) Analysis of gene order conservation in eukaryotes identifies transcriptionally and functionally linked genes. PLoS One 5: e10654

Delaye L, DeLuna A, Lazcano A, Becerra A (2008) The origin of a novel gene through overprinting in Escherichia coli. BMC Evolutionary Biology 8: 31

Denhardt DT, Sinsheimer RL (1965) The process of infection with bacteriophage $\phi X 174$ : III. Phage maturation and lysis after synchronized infection. Journal of Molecular Biology 12: 641-646

Ding Y-h, Duda RL, Hendrix RW, Rosenberg JM (1995) Complexes between chaperonin GroEL and the capsid protein of bacteriophage HK97. Biochemistry 34: 14918-14931

Dokland T, McKenna R, Ilag LL, Bowman BR, Incardona NL, Fane BA, Rossmann MG (1997) Structure of a viral procapsid with molecular scaffolding. Nature 389: 308-313

Doore SM, Baird CD, Lab. TUoAVU, Roznowski AP, Fane BA (2014) The Evolution of Genes within Genes and the Control of DNA Replication in Microviruses. Molecular Biology and Evolution 31: 1421-1431

Dowell CE (1967) Cold-sensitive mutants of bacteriophage phi-X-174. I. A mutant blocked in the eclipse function at low temperature. Proc Natl Acad Sci U S A 58: 958-961

Eisenberg S, Ascarelli R (1981) The A* protein of phi X174 is an inhibitor of DNA replication. Nucleic acids research 9: 1991-2002

Emerson SU, Arankalle VA, Purcell RH (2005) Thermal Stability of Hepatitis E Virus. The Journal of Infectious Diseases 192: 930-933

Endy D, You L, Yin J, Molineux IJ (2000) Computation, prediction, and experimental tests of fitness for bacteriophage T7 mutants with permuted genomes. Proceedings of the National Academy of Sciences 97: 5375

Erdemci-Tandogan G, Wagner J, van der Schoot P, Podgornik R, Zandi R (2014) RNA topology remolds electrostatic stabilization of viruses. Physical Review E 89: 032707

Evilevitch A, Fang LT, Yoffe AM, Castelnovo M, Rau DC, Parsegian VA, Gelbart WM, Knobler CM (2008) Effects of Salt Concentrations and Bending Energy on the Extent of Ejection of Phage Genomes. Biophysical Journal 94: 1110-1120

Evilevitch A, Lavelle L, Knobler CM, Raspaud E, Gelbart WM (2003) Osmotic pressure inhibition of DNA ejection from phage. Proceedings of the National Academy of Sciences 100: 9292

Fernandes JD, Faust TB, Strauli NB, Smith C, Crosby DC, Nakamura RL, Hernandez RD, Frankel AD (2016) Functional Segregation of Overlapping Genes in HIV. Cell 167: 1762-1773.e12

Fernandez-Leiro R, Scheres SHW (2017) A pipeline approach to single-particle processing in RELION. Acta Crystallogr D Struct Biol 73: 496-502

Flanagan EB, Schoeb TR, Wertz GW (2003) Vesicular stomatitis viruses with rearranged genomes have altered invasiveness and neuropathogenesis in mice. J Virol 77: 5740-8 
Gallet R, Kannoly S, Wang I-N (2011) Effects of bacteriophage traits on plaque formation. BMC Microbiology 11: 181

Geller R, Taguwa S, Frydman J (2012) Broad action of Hsp90 as a host chaperone required for viral replication. Biochimica et Biophysica Acta (BBA)-Molecular Cell Research 1823: 698-706

Ghosh D, Kohli AG, Moser F, Endy D, Belcher AM (2012) Refactored M13 bacteriophage as a platform for tumor cell imaging and drug delivery. ACS synthetic biology 1: 576-582

Gillam S, Atkinson T, Markham A, Smith M (1985) Gene K of bacteriophage phi X174 codes for a protein which affects the burst size of phage production. J Virol 53: 708-9

Hafenstein S, Fane BA (2002) phi X174 genome-capsid interactions influence the biophysical properties of the virion: evidence for a scaffolding-like function for the genome during the final stages of morphogenesis. J Virol 76: 5350-6

Hafenstein SL, Chen M, Fane BA (2004) Genetic and functional analyses of the oX174 DNA binding protein: the effects of substitutions for amino acid residues that spatially organize the two DNA binding domains. Virology 318: 204-13

Hanninen AL, Bamford DH, Bamford JK (1997) Assembly of membrane-containing bacteriophage PRD1 is dependent on GroEL and GroES. Virology 227: 207-10

Harmston N, Ing-Simmons E, Tan G, Perry M, Merkenschlager M, Lenhard B (2017) Topologically associating domains are ancient features that coincide with Metazoan clusters of extreme noncoding conservation. Nature Communications 8: 441

Herniou EA, Olszewski JA, Cory JS, O'Reilly DR (2003) The Genome Sequence and Evolution of Baculoviruses. Annual Review of Entomology 48: 211-234

Hutchison CA, Chuang R-Y, Noskov VN, Assad-Garcia N, Deerinck TJ, Ellisman MH, Gill J, Kannan K, Karas BJ, Ma L, Pelletier JF, Qi Z-Q, Richter RA, Strychalski EA, Sun L, Suzuki Y, Tsvetanova B, Wise KS, Smith HO, Glass $\mathrm{Jl}$ et al. (2016) Design and synthesis of a minimal bacterial genome. Science (New York, NY) 351: aad6253

Hutchison CA, Sinsheimer RL (1966) The process of infection with bacteriophage $\Phi \times 174$ : X. Mutations in a ФX lysis gene. Journal of Molecular Biology 18: 429-IN2

Huvet M, Stumpf MPH (2014) Overlapping genes: a window on gene evolvability. BMC genomics 15: 721721

Ilag LL, Incardona NL (1993) Structural basis for bacteriophage phi X174 assembly and eclipse as defined by temperature-sensitive mutations. Virology 196: 758-68

Incardona NL (1974) Mechanism of adsorption and eclipse of bacteriophage phi chi 174. 3. Comparison of the activation parameters for the in vitro and in vivo eclipse reactions with mutant and wild-type virus. $J$ Virol 14: 469-78

Ivanovska I, Wuite G, Jönsson B, Evilevitch A (2007) Internal DNA pressure modifies stability of WT phage. Proceedings of the National Academy of Sciences 104: 9603-9608

Jaschke PR, Dotson GA, Hung KS, Liu D, Endy D (2019) Definitive demonstration by synthesis of genome annotation completeness. Proceedings of the National Academy of Sciences 116: 24206-24213

Jaschke PR, Lieberman EK, Rodriguez J, Sierra A, Endy D (2012) A fully decompressed synthetic bacteriophage $\varnothing$ X174 genome assembled and archived in yeast. Virology 434: 278-284 
Jin H, Vacic V, Girke T, Lonardi S, Zhu J-K (2008) Small RNAs and the regulation of cis-natural antisense transcripts in Arabidopsis. BMC Molecular Biology 9: 6

Johnson ZI, Chisholm SW (2004) Properties of overlapping genes are conserved across microbial genomes. Genome Res 14: 2268-72

Keese PK, Gibbs A (1992) Origins of genes: big bang or continuous creation? Proceedings of the National Academy of Sciences 89: 9489

Kropinski AM, Mazzocco A, Waddell TE, Lingohr E, Johnson RP (2009) Enumeration of bacteriophages by double agar overlay plaque assay. Methods in molecular biology (Clifton, NJ) 501: 69-76

Lajoie MJ, Kosuri S, Mosberg JA, Gregg CJ, Zhang D, Church GM (2013) Probing the limits of genetic recoding in essential genes. Science (New York, NY) 342: 361-3

Lanctôt C, Cheutin T, Cremer M, Cavalli G, Cremer T (2007) Dynamic genome architecture in the nuclear space: regulation of gene expression in three dimensions. Nature Reviews Genetics 8: 104-115

Lapidot M, Pilpel Y (2006) Genome-wide natural antisense transcription: coupling its regulation to its different regulatory mechanisms. EMBO Rep 7: 1216-1222

Lawrence JG (2002) Shared Strategies in Gene Organization among Prokaryotes and Eukaryotes. Cell 110: 407-413

Li G-q, Ma T, Li S-s, Li H, Liang F-I, Liu R-I (2007) Improvement of Dibenzothiophene Desulfurization Activity by Removing the Gene Overlap in the dsz Operon. Bioscience, Biotechnology, and Biochemistry 71: 849-854

Lim HN, Lee $Y$, Hussein R (2011) Fundamental relationship between operon organization and gene expression. Proceedings of the National Academy of Sciences 108: 10626

Lorenz R, Bernhart SH, Höner zu Siederdissen C, Tafer H, Flamm C, Stadler PF, Hofacker IL (2011) ViennaRNA Package 2.0. Algorithms for Molecular Biology 6: 26

MacLean B, Tomazela DM, Shulman N, Chambers M, Finney GL, Frewen B, Kern R, Tabb DL, Liebler DC, MacCoss MJ (2010) Skyline: an open source document editor for creating and analyzing targeted proteomics experiments. Bioinformatics 26: $966-968$

Mateo R, Luna E, Rincón V, Mateu MG (2008) Engineering Viable Foot-and-Mouth Disease Viruses with Increased Thermostability as a Step in the Development of Improved Vaccines. Journal of Virology 82: $12232-12240$

Mayer M (2005) Recruitment of Hsp70 chaperones: a crucial part of viral survival strategies. In Reviews of physiology, biochemistry and pharmacology, pp 1-46. Springer

McKenna R, Xia D, Willingmann P, Ilag LL, Krishnaswamy S, Rossmann MG, Olson NH, Baker TS, Incardona $\mathrm{NL}$ (1992) Atomic structure of single-stranded DNA bacteriophage phi X174 and its functional implications. Nature 355: 137-143

Minot S, Wu GD, Lewis JD, Bushman FD (2012) Conservation of gene cassettes among diverse viruses of the human gut. PLoS One 7: e42342-e42342

Mouilleron H, Delcourt V, Roucou X (2015) Death of a dogma: eukaryotic mRNAs can code for more than one protein. Nucleic acids research 44: 14-23

Neme R, Tautz D (2013) Phylogenetic patterns of emergence of new genes support a model of frequent de novoevolution. BMC Genomics 14: 117 
Newbold JE, Sinsheimer RL (1970a) Process of infection with bacteriophage phi-X174. XXXIV. Kinetic of the attachment and eclipse steps of the infection. J Virol 5: 427-31

Newbold JE, Sinsheimer RL (1970b) The process of infection with bacteriophage $\phi X 174$ : XXXI. Abortive infection at low temperatures. Journal of Molecular Biology 49: 23-47

Newbold JE, Sinsheimer RL (1970c) The process of infection with bacteriophage $\phi X 174$ : XXXII. Early steps in the infection process: Attachment, eclipse and DNA penetration. Journal of Molecular Biology 49: 49-66

Novak CR, Fane BA (2004) The functions of the $\mathrm{N}$ terminus of the phiX174 internal scaffolding protein, a protein encoded in an overlapping reading frame in a two scaffolding protein system. J Mol Biol 335: 38390

Ojosnegros S, García-Arriaza J, Escarmís C, Manrubia SC, Perales C, Arias A, Mateu MG, Domingo E (2011) Viral Genome Segmentation Can Result from a Trade-Off between Genetic Content and Particle Stability. PLOS Genetics 7: e1001344

Pavesi A, Vianelli A, Chirico N, Bao Y, Blinkova O, Belshaw R, Firth A, Karlin D (2018) Overlapping genes and the proteins they encode differ significantly in their sequence composition from non-overlapping genes.

PLoS One 13: e0202513-e0202513

Pesko K, Voigt EA, Swick A, Morley VJ, Timm C, Yin J, Turner PE (2015) Genome rearrangement affects RNA virus adaptability on prostate cancer cells. Frontiers in Genetics 6

Peterson AC, Russell JD, Bailey DJ, Westphall MS, Coon JJ (2012) Parallel reaction monitoring for high resolution and high mass accuracy quantitative, targeted proteomics. Molecular \& Cellular Proteomics 11: $1475-1488$

Poyatos JF, Hurst LD (2007) The determinants of gene order conservation in yeasts. Genome Biology 8: R233

Roof WD, Horne SM, Young KD, Young R (1994) slyD, a host gene required for phi X174 lysis, is related to the FK506-binding protein family of peptidyl-prolyl cis-trans-isomerases. The Journal of biological chemistry 269: $2902-10$

Roos WH, Bruinsma R, Wuite GJL (2010) Physical virology. Nature Physics 6: 733-743

Roznowski AP, Doore SM, Kemp SZ, Fane BA (2019) Finally, a role befitting Astar: the strongly conserved, unessential microvirus $A^{*}$ proteins ensure the product fidelity of packaging reactions. Journal of Virology: JVI.01593-19

Saha B, Wong CM, Parks RJ (2014) The adenovirus genome contributes to the structural stability of the virion. Viruses 6: 3563-83

Sanna CR, Li W-H, Zhang L (2008) Overlapping genes in the human and mouse genomes. BMC Genomics 9: 169

Scheres SH (2012a) A Bayesian view on cryo-EM structure determination. J Mol Biol 415: 406-18

Scheres SHW (2012b) RELION: Implementation of a Bayesian approach to cryo-EM structure determination. Journal of Structural Biology 180: 519-530

Schlub TE, Holmes EC (2020) Properties and abundance of overlapping genes in viruses. Virus Evolution 6

Šiber A, Božič AL, Podgornik R (2012) Energies and pressures in viruses: contribution of nonspecific electrostatic interactions. Physical Chemistry Chemical Physics 14: 3746-3765 
Siden EJ, Hayashi M (1974) Role of the gene B product in bacteriophage $\phi X 174$ development. Journal of Molecular Biology 89: 1-16

Singer GAC, Lloyd AT, Huminiecki LB, Wolfe KH (2004) Clusters of Co-expressed Genes in Mammalian Genomes Are Conserved by Natural Selection. Molecular Biology and Evolution 22: 767-775

Snijder J, Uetrecht C, Rose RJ, Sanchez-Eugenia R, Marti GA, Agirre J, Guérin DMA, Wuite GJL, Heck AJR, Roos WH (2013) Probing the biophysical interplay between a viral genome and its capsid. Nature Chemistry 5: 502-509

Springman R, Badgett MR, Molineux IJ, Bull JJ (2005) Gene order constrains adaptation in bacteriophage T7. Virology 341: 141-152

Sun H, Yang S, Tun L, Li Y (2015) IAOseq: inferring abundance of overlapping genes using RNA-seq data. BMC Bioinformatics 16 Suppl 1: S3-S3

Sun Y, Roznowski AP, Tokuda JM, Klose T, Mauney A, Pollack L, Fane BA, Rossmann MG (2017) Structural changes of tailless bacteriophage $\Phi \times 174$ during penetration of bacterial cell walls. Proceedings of the National Academy of Sciences 114: 13708

Tamames J (2001) Evolution of gene order conservation in prokaryotes. Genome Biology 2: research0020.1

Tsochatzidou M, Malliarou M, Papanikolaou N, Roca J, Nikolaou C (2017) Genome urbanization: clusters of topologically co-regulated genes delineate functional compartments in the genome of Saccharomyces cerevisiae. Nucleic acids research 45: 5818-5828

Van Leuven JT, Ederer MM, Burleigh K, Scott L, Hughes RA, Codrea V, Ellington AD, Wichman H, Miller C (2020) ФX174 Attenuation by Whole Genome Codon Deoptimization. bioRxiv: 2020.02.10.942847

van Mansfeld AD, van Teeffelen HA, Fluit AC, Baas PD, Jansz HS (1986) Effect of SSB protein on cleavage of single-stranded DNA by phi $X$ gene A protein and A* protein. Nucleic Acids Res 14: 1845-61

Van Oss SB, Carvunis A-R (2019) De novo gene birth. PLOS Genetics 15: e1008160

Veeramachaneni V, Makałowski W, Galdzicki M, Sood R, Makałowska I (2004) Mammalian overlapping genes: the comparative perspective. Genome research 14: 280-286

Wakimoto BT, Hearn MG (1990) The effects of chromosome rearrangements on the expression of heterochromatic genes in chromosome 2L of Drosophila melanogaster. Genetics 125: 141-154

Xiao A, Wong J, Luo H (2010) Viral interaction with molecular chaperones: role in regulating viral infection. Archives of virology 155: 1021-1031

Yazaki K (1981) Electron microscopic studies of bacteriophage phi X174 intact and "eclipsing' particles, and the genome by the staining, and shadowing method. J Virol Methods 2: 159-67

Zadeh JN, Steenberg CD, Bois JS, Wolfe BR, Pierce MB, Khan AR, Dirks RM, Pierce NA (2011) NUPACK: Analysis and design of nucleic acid systems. J Comput Chem 32: 170-3

Zeng C, Hernando-Perez M, Dragnea B, Ma X, van der Schoot P, Zandi R (2017a) Contact Mechanics of a Small Icosahedral Virus. Phys Rev Lett 119: 038102

Zeng C, Moller-Tank S, Asokan A, Dragnea B (2017b) Probing the Link among Genomic Cargo, Contact Mechanics, and Nanoindentation in Recombinant Adeno-Associated Virus 2. J Phys Chem B 121: 1843-1853

Zhang K (2016) Gctf: Real-time CTF determination and correction. J Struct Biol 193: 1-12 
Zheng SQ, Palovcak E, Armache JP, Verba KA, Cheng Y, Agard DA (2017) MotionCor2: anisotropic correction of beam-induced motion for improved cryo-electron microscopy. Nat Methods 14: 331-332

Zheng Y, Struck DK, Young R (2009) Purification and Functional Characterization of ?X174 Lysis Protein E. Biochemistry 48: 4999-5006

Zivanov J, Nakane T, Forsberg BO, Kimanius D, Hagen WJH, Lindahl E, Scheres SHW (2018) New tools for automated high-resolution cryo-EM structure determination in RELION-3. eLife 7: e42166

Zuker M (2003) Mfold web server for nucleic acid folding and hybridization prediction. Nucleic acids research 31: 3406-3415 